\title{
Detector electrode introduced by mediastinoscopy for atrial triggered cardiac pacing A follow-up study of electrode function in 82 patients
}

\author{
E. CARLENS, M. ERICSSON, M. LEVANDER-LINDGREN, \\ AND K. PEHRSSON
}

From the Pacemaker Unit of the Department of Medicine and the Department of Thoracic Surgery, Karolinska Hospital, Stockholm, Sweden

An atrial detector electrode was introduced by mediastinoscopy in 82 patients requiring permanent cardiac pacing. There were no complications. An adequate $P$ wave was recorded in 80 patients. During the following week, the $P$ wave became ineffective in 5 patients; angina occurred in 2 and atrial arrhythmias in 2 . Atrially triggered ventricular pacing was established in 73 patients and was followed in 71 patients for a period of 1 to 113 months. In 7 cases, it had to be terminated because of an ineffective or unstable $P$ wave, in 6 cases because of atrial arrhythmias, and in 4 cases because of advanced age and recurrent infections.

The method is technically simple and places little stress on the patient.

When permanent cardiac pacing was introduced (Weirich et al., 1957; Furman and Schwedel, 1959; Glenn et al., 1959; Senning, 1959; Elmqvist and Senning, 1960) the aim was to prevent AdamsStokes attacks and death in patients with complete heart block. Fixed rate cardiac pacing meant an enormous benefit to these patients. With technical progress, greater demands have been made on cardiac pacing in order to avoid potentially dangerous interference between pacemaker rhythm and spontaneous beats and to help patients live a normal life without feeling discomfort or incapacity. Atrial triggered cardiac pacing means for many patients the achievement of this aim. The method was described in animal experiments by Folkman and Watkins (1957), Stephenson et al. (1959), Battye and Wheale (1960), and Nathan et al. (1963). It was introduced in the clinic by Center et al. (1963), who used an atrial sensing electrode introduced by thoracotomy.

At the Karolinska hospital atrial triggered cardiac pacing was introduced by Carlens et al. (1965) and Lagergren et al. $(1966 \mathrm{a}, \mathrm{b})$ by means of an atrial sensing electrode introduced by mediastinoscopy (Carlens, 1959). The present paper reports a followup of operative results, the primary and late effectiveness of this type of atrial sensing electrode, and the cause of terminating atrial triggered cardiac pacing in all patients treated in this hospital by this method since 1964.

Received for publication 1 November 1976

\section{Method}

In the first stage a transvenous cardiac electrode was implanted and connected to an external pulse generator. During the past few years the stability of sinus rhythm and the amplitude of the $P$ wave have been tested at rest and during exercise by means of an oesophageal electrode before implanting the mediastinal atrial sensing electrode. Fig. 1 shows the position of the mediastinal atrial electrode and Fig. 2 shows the close relation between it and the oesophageal electrode. Fig. 3 shows the $P$ waves simultaneously recorded from both electrodes and Fig. 4 the standard leads with the atrial triggered cardiac pacemaker. The electrode used for mediastinal implantation was the Siemens-Elema EMT 588, and implantation was performed under general anaesthesia. A small incision was made in the jugular fossa and the front of the trachea was dissected. Under visual control through the mediastinoscope the dissection was continued by a $3 \mathrm{~mm}$ thick closed end suction tube past the point of bifurcation of the trachea and behind the right branch of the pulmonary artery to reach the layer of the connective tissue between the posterior wall of the left atrium and the oesophagus. Attempts were made to make a narrow tunnel slightly to the left of the midline. Best results were usually achieved 4 to $5 \mathrm{~cm}$ below the carina level. When this region had been located the electrode tip was gently advanced and, with the aid of forceps, placed in the 


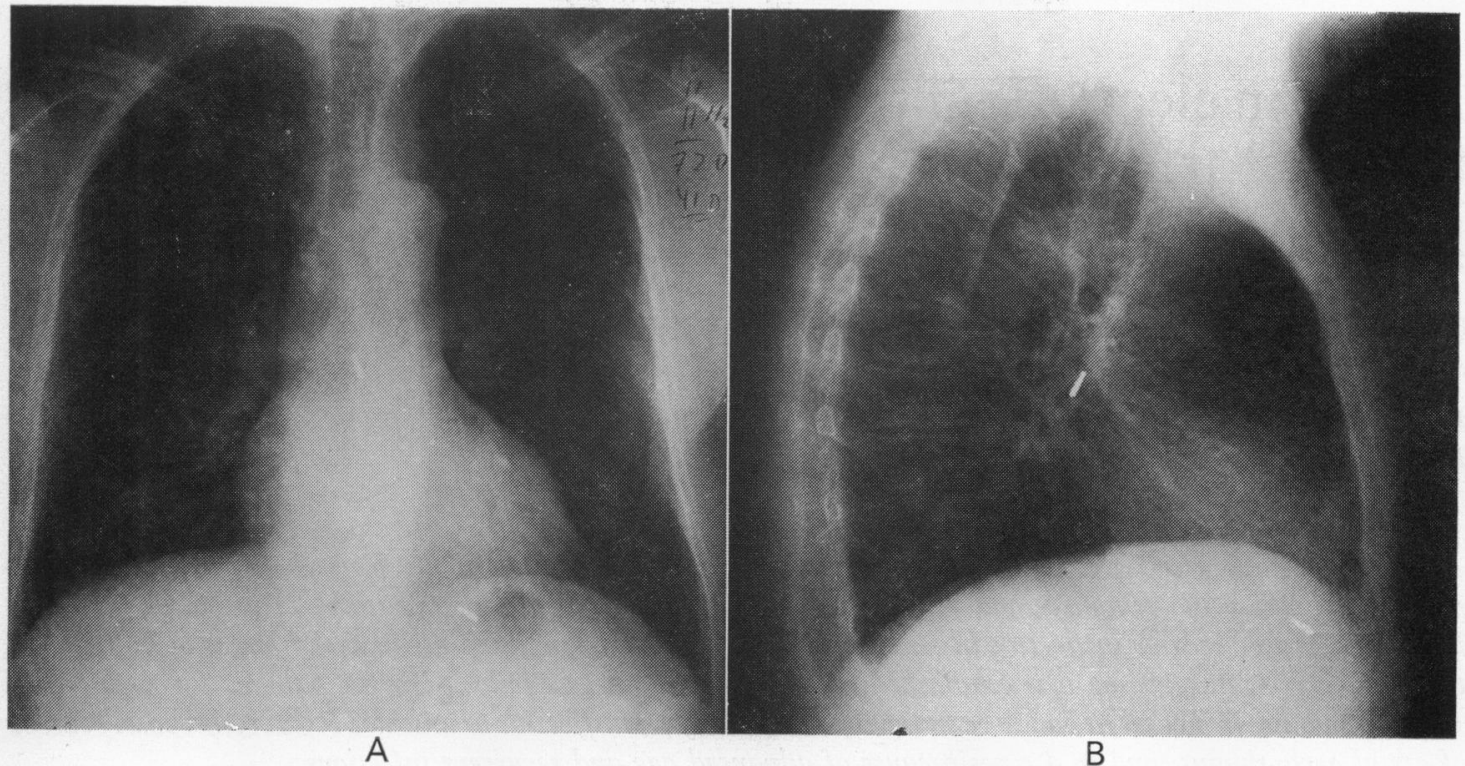

Fig. $1 \mathrm{X}$-ray film in anteroposterior $(A)$ and lateral $(B)$ views visualising the mediastinal and the ventricular electrode in adequate position.

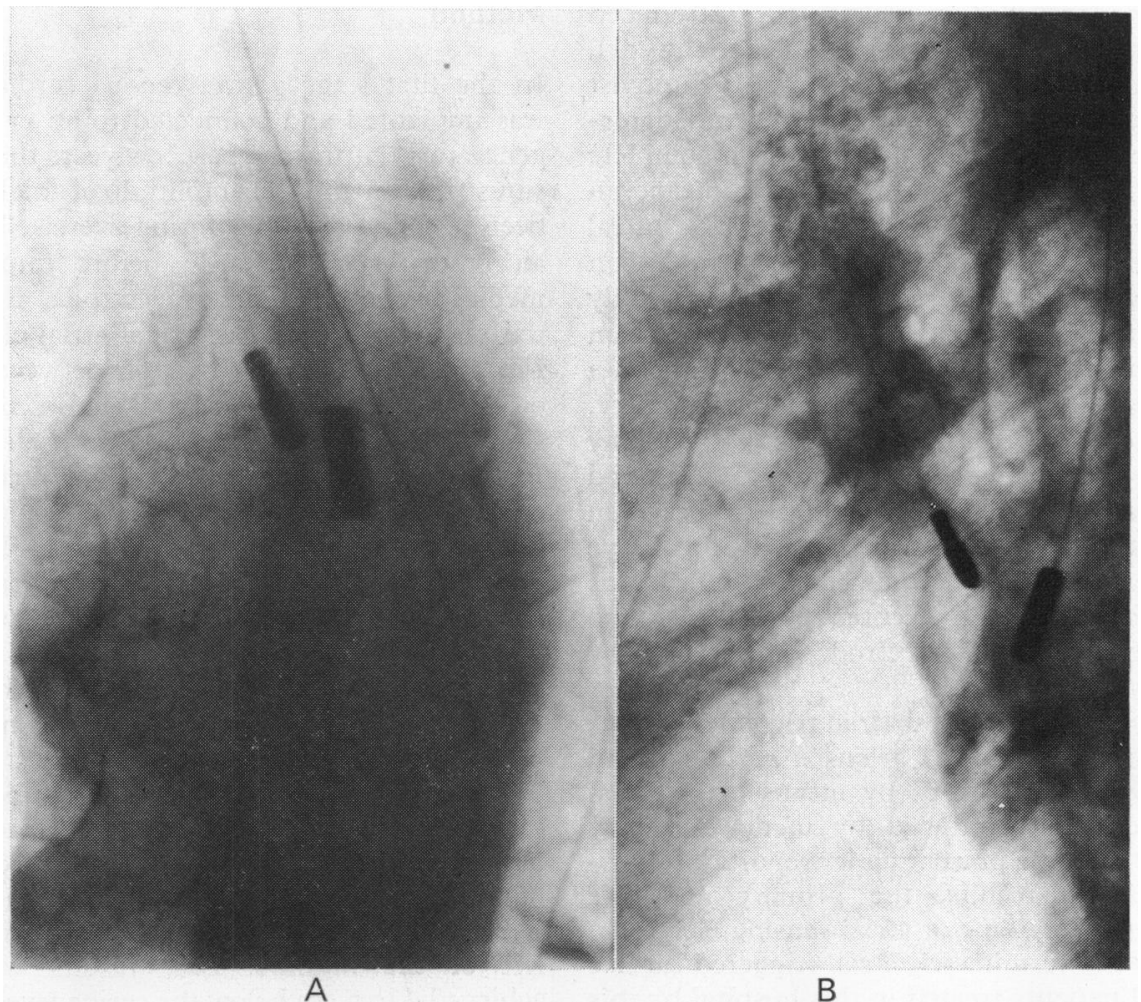

Fig. $2 \mathrm{X}$-ray in antero $(A)$ and lateral $(B)$ views showing the close relation between the mediastinal and the oesophageal electrode. The upper electrode belongs to the mediastinal atrial electrode. 
connective tissue as close as possible to the atrial wall, while the amplitude of the $P$ wave was checked on the electrocardiogram. Forcing the suction tube down involves the risk of both puncturing the pericardium and placing the electrode in an unstable position.

The amplitude from the positive to the negative deflection of the $P$ wave was measured between the

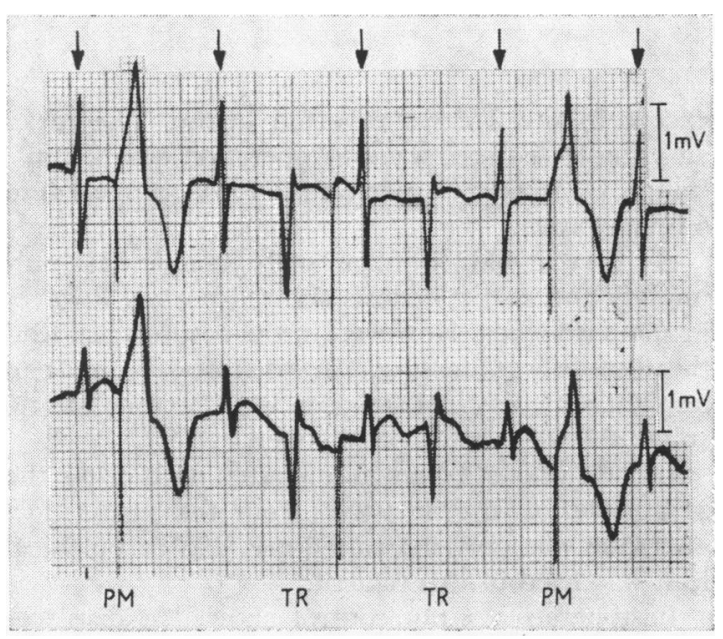

Fig. 3 Electrocardiogram from mediastinal atrial electrode and oesophageal electrode. Upper row, recording between the right arm and the mediastinal electrode. The mediastinal atrial electrode is, thus, not connected to the atrial triggered pulse generator which is stimulating at its basic rate: 52 beats per min.

Lower row: recording between the right arm and an oesophageal electrode. The recording was made at the same time as the $\mathrm{x}$-ray film shown in Fig. 2. P waves are indicated by arrows and resemble each other in the two leads. There are both transmitted $Q R S$ complexes (TR) and pacemaker induced $Q R S$ complexes (PM). The second pacer artefact arrives in the refractory period. Paper speed : $25 \mathrm{~mm}$ per second. mediastinal atrial electrode and the right arm. The amplitude was not significantly different if the reference electrode was placed in the region of the generator pocket in the abdominal wall. More recently the positive and negative deflection of the $\mathbf{P}$ wave was measured separately because the input sensitivity of the pulse generator is more closely related to the positive and the negative deflections of the $P$ wave rather than to the total amplitude. In order to get comparable values the total amplitude is given on the figures.

During the first period of this study a SiemensElema EM 141 pulse generator was used, requiring a $P$ wave amplitude of at least $0.9 \mathrm{mV}$. Later on the more sensitive pulse generator, Siemens-Elema EM 144, EM 156/50, was constructed, which was triggered by a $P$ wave of 0.5 to $0.4 \mathrm{mV}$.

When the $P$ wave reached a stable value of at least 1 to $1.5 \mathrm{mV}$ a loop was made in the neck and the electrode cable was drawn stepwise subcutaneously by means of a long injection needle, over the chest and abdomen to the left groin. The long subcutaneous tunnel minimised the risk of infection. The procedure, which has undergone only minor variations since it was first introduced, places very little strain on the patient.

If a second intervention for correction of the electrode placement was undertaken, varying degrees of scar formation could be found anterior to the trachea. In such cases the soft tissue to the right of the trachea was dissected. At the level of the right main bronchus a narrow tunnel was then dissected by the suction tube to the left of the midline.

The amplitude of the $P$ wave after the operation often decreased during the first week after implantation and was checked repeatedly during 10 days. Before the atrial triggered generator was implanted the patient was tested with an externally coupled atrial triggered pulse generator at rest and during exercise. The amplitude of the $P$ wave was thereafter routinely measured when replacement of the pulse generator was made.

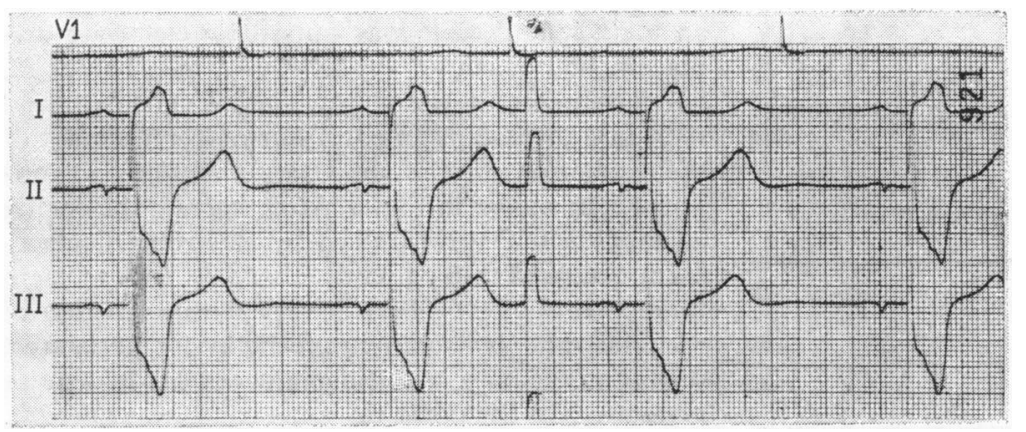

Fig. 4 Electrocardiogram with atrial triggered cardiac pacing. Standard leads with the mediastinal electrode connected to the atrial triggered pulse generator in the same patient as in Fig. 1, 2, and 3. The small negative deflection of the $P$ wave in leads II and III is caused by the $P$ wave triggering the pulse. generator. Paper speed: $50 \mathrm{~mm}$ per second. 
Table 1 Review of case material

\begin{tabular}{|c|c|c|c|c|c|c|}
\hline No. of patients & $\begin{array}{l}\text { Age } \\
\text { Mean } \pm S D \text { (range) }\end{array}$ & $\begin{array}{l}\text { No. starting atrial } \\
\text { triggered cardiac } \\
\text { pacing }\end{array}$ & $\begin{array}{l}\text { Duration of atrial } \\
\text { triggered cardiac } \\
\text { pacing } \\
\text { No. mean } \pm S D \\
\text { months (range) }\end{array}$ & $\begin{array}{l}\text { No. terminating atrial } \\
\text { triggered cardiac } \\
\text { pacing }\end{array}$ & No. of deaths & $\begin{array}{l}\text { No. of patients still } \\
\text { undergoing atrial } \\
\text { triggered cardiac } \\
\text { pacing }\end{array}$ \\
\hline $\begin{array}{l}\text { Men } \\
\mathbf{4 4}\end{array}$ & $\begin{array}{l}55 \pm 11 \\
(26-70)\end{array}$ & 40 & $\begin{array}{l}39 \star \\
39 \pm 5 \\
(1-103)\end{array}$ & 8 & 7 & 24 \\
\hline $\begin{array}{l}\text { Women } \\
38\end{array}$ & $\begin{array}{l}52 \pm 13 \\
(29-69)\end{array}$ & 33 & $\begin{array}{l}32^{\star} \\
46 \pm 6 \\
(4-113)\end{array}$ & 9 & 2 & 21 \\
\hline
\end{tabular}

$\star_{1}$ patient lost from follow-up.

\section{Subjects}

The present study was based on 82 patients, 44 men and 38 women. The mean age was 55 years for men and 52 years for women (range 26 to 70 years) (Table 1). All patients in whom an attempt was made to introduce a mediastinal atrial pacing electrode in the period from 1964 to May 1974 were included in the study and all patients continuing to attend the Karolinska hospital for pulse generator replacements were included in the follow-up. In a few cases complementary information was obtained from hospitals outside the region of Stockholm.

In 9 patients atrial triggered cardiac pacing was not started (Table 2), and 2 patients with this type of pacing were lost from the follow-up.

The observation period in the remaining 71 patients ranged from 1 to 113 months. The mean observation period was $39 \pm 5$ SD months for men and $46 \pm 6 \mathrm{SD}$ months for women. During this control period 7 men and 2 women died. Death in 5 cases was not caused by pacemaker defect. In the remaining 4 cases the cause was unknown. In 17 cases ( 8 men and 9 women) atrial pacing had to be terminated. The reasons for this are discussed later. At the time of writing there are 45 cases $(24$ men and 21 women) still undergoing treatment.

\section{Results}

PRIMARY OPERATIVE RESULTS

An acceptable $P$ wave with an amplitude of at least 1.0 to $1.5 \mathrm{mV}$ was achieved in all patients

Table 2 Different causes of not starting atrial triggered cardiac pacing

\begin{tabular}{lllll}
\hline $\begin{array}{l}\text { Ineffective } \\
\begin{array}{l}\text { wave } \\
\text { preoperatively }\end{array}\end{array}$ & $\begin{array}{l}\text { Ineffective } \\
\begin{array}{l}\text { wave } \\
\text { postoperatively }\end{array}\end{array}$ & $\begin{array}{l}\text { Anginal } \\
\text { pains }\end{array}$ & $\begin{array}{l}\text { Sinoatrial } \\
\text { block }\end{array}$ & $\begin{array}{l}\text { Atrial } \\
\text { fibrillation }\end{array}$ \\
\hline 2 & 3 & 2 & 1 & 1 \\
\hline
\end{tabular}

except in the 2 cases reported below. The mean amplitude of the $P$ wave at operation was $2.8 \mathrm{mV}$ (range 1.3 to 5.0 ) in men and $2.5 \mathrm{mV}$ (range 1.0 to 6.0 ) in women.

A 38-year-old woman with congenital pulmonary and aortic stenosis showed normal $P$ waves in standard leads. However, in the oesophageal lead the $\mathbf{P}$ wave was missing. An attempt was made to implant a mediastinal atrial pacing electrode but no suitable $P$ wave could be obtained.

In a 68-year-old woman, operated on in 1964, the amplitude of the $P$ wave from the mediastinal electrode was only 0.3 to $0.4 \mathrm{mV}$. No oesophageal lead was tried in this patient.

Postoperative $x$-ray control showed a displacement of the electrode into the pericardium in 2 patients but its position was easily adjusted: 1 of the 2 patients developed atrial fibrillation, which was converted, and when fibrillation subsequently recurred it was decided not to start atrial triggered cardiac pacing. In a third patient pleuropericarditis was observed 4 weeks after implantation; the exudate regressed spontaneously.

\section{AMPLITUDE OF P WAVE}

During the first week after the implantation of mediastinal atrial pacing electrode there was often a decrease of about 1 to $2 \mathrm{mV}$ in the amplitude of the $P$ wave (Fig. 5). In 2 of the 78 patients this decrease caused an inefficient $P$ wave. In another 4 patients an inefficient $P$ wave was caused by electrode displacement visualised by $x$-ray film (Table 3 ). Measurements of the $P$ wave after starting atrial triggered cardiac pacing and during replacement of the generator showed moderate variations in amplitude, as shown in Fig. 6. After starting the pacing an inefficient $\mathbf{P}$ wave caused by electrode displacement occurred in 6 patients (Table 3). In 3 of them there had obviously been a very strong traction of the electrode by rotation of the pulse generator, during pregnancy or during replacement of a pulse generator. In the other cases the cause was obscure. 
In one patient a broken electrode, which was easily repaired, caused an ineffective $P$ wave.

\section{CORRECTED AND RENEWED}

ELECTRODE IMPLANTATION

In 9 out of 13 patients with an inefficient $P$ wave, attempts were made to correct or reimplant the mediastinal atrial electrode. In the other 4 patients already undergoing atrial triggered cardiac pacing this treatment was considered of less value for a variety of reasons, including advanced age. Out of the 4 cases in which an attempt was made to correct the mediastinal atrial electrode, one was successful one day after implantation and one successful one year after implantation. The two unsuccessful cases

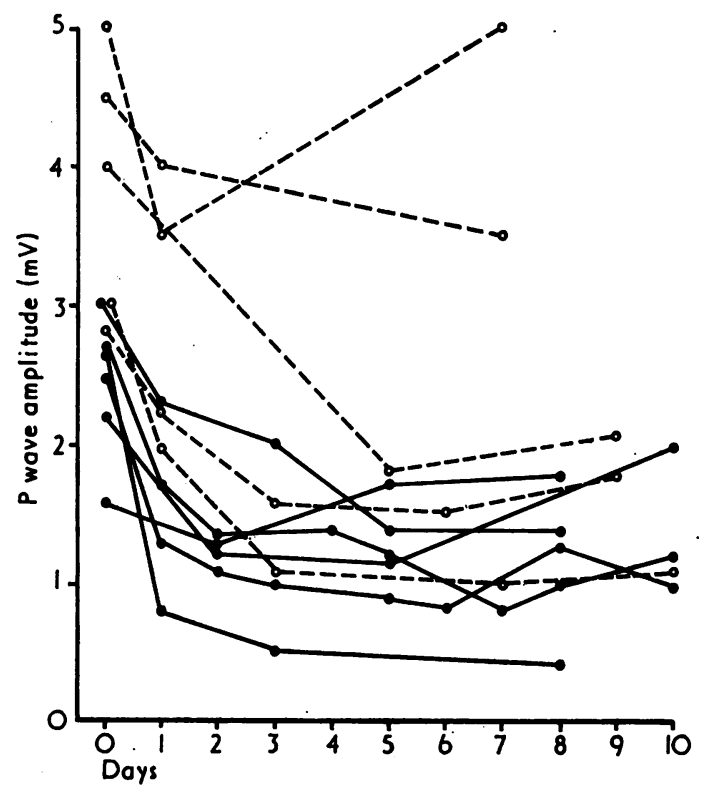

Fig. $5 P$ wave amplitude in 11 cases illustrating the typical decrease of the amplitude during the first 10 days; men $=0$, women $=0$. had displaced electrodes before starting atrial triggered cardiac pacing. Reimplantation functioned well in 4 out of 5 patients. In the fifth case, a 47year-old woman, the second electrode became dislocated after 2 months. A third attempt was made but failed because of scar tissue in the mediastinum.

\section{TERMINATED ATRIAL TRIGGERED}

\section{CARDIAC PACING}

Atrial triggered cardiac pacing was terminated in 17 cases for the various reasons shown in Table 4.

Table 4 Different causes of termination of atrial triggered cardiac pacing

\begin{tabular}{llllll}
\hline $\begin{array}{l}\text { Total } \\
\text { No. }\end{array}$ & $\begin{array}{l}\text { Inefficient } \\
P \text { vave }\end{array}$ & $\begin{array}{l}\text { Unstable } \\
P \text { wave }\end{array}$ & $\begin{array}{l}\text { Sinus } \\
\text { bradycardia } \\
\text { or arrest }\end{array}$ & $\begin{array}{l}\text { Atrial flutter } \\
\text { or fibrillation }\end{array}$ \\
\hline 17 & 4 & 3 & 4 & 2 & 4 \\
see text
\end{tabular}

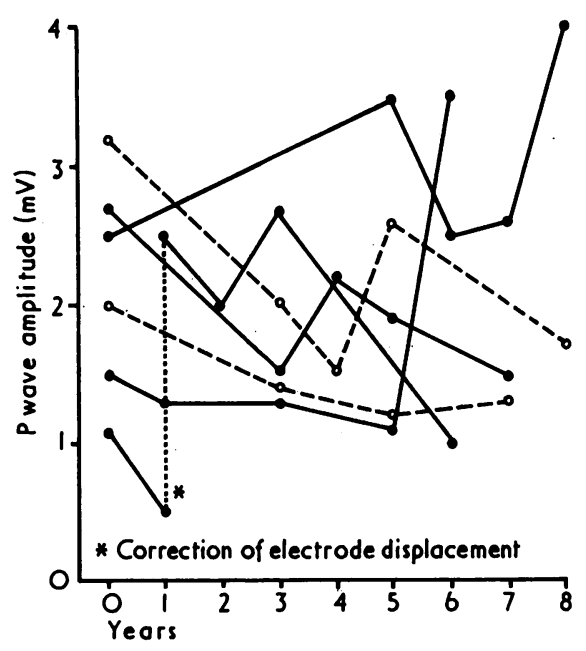

Fig. $6 P$ wave amplitude in 6 cases illustrating the variation of the amplitude during treatment; men $=0$, women $=0$.

Table 3 Follow-up of primary $P$ wave

\begin{tabular}{|c|c|c|c|c|}
\hline $\begin{array}{l}\text { Acceptable at operation } \\
\text { No. }\end{array}$ & $\begin{array}{l}\text { Inefficient before generator } \\
\text { implant } \\
\text { No. }\end{array}$ & $\begin{array}{l}\text { Displacement before } \\
\text { generator implant } \\
\text { No. }\end{array}$ & $\begin{array}{l}\text { Inefficient after starting } \\
\text { atrial triggered cardiac } \\
\text { pacing } \\
\text { No. }\end{array}$ & $\begin{array}{l}\text { Displacement after starting } \\
\text { atrial triggered cardiac } \\
\text { pacing } \\
\text { No. }\end{array}$ \\
\hline $\begin{array}{l}\text { Men } 44 \\
\text { Women } 36\end{array}$ & $\begin{array}{l}3 \\
4^{\star}\end{array}$ & $\begin{array}{l}2 \\
2\end{array}$ & $\begin{array}{l}4 t \\
3\end{array}$ & $\begin{array}{l}3 \\
3\end{array}$ \\
\hline Total 80 & 7 & 4 & 7 & 6 \\
\hline
\end{tabular}

$\star_{1}$ patient without $x$-ray control of the electrode position. +1 patient with a broken cable. 
The 4 cases ( 3 men and 1 woman) under the heading of 'other causes' include 2 of the men who developed other incapacitating illnesses during atrial triggered cardiac pacing.

The third man had developed atrioventricular block because of myocarditis, and during replacement of a pulse generator two years later it became apparent that the atrioventricular conduction was normal. $\mathrm{He}$ was, therefore, given ventricular triggered pacing in order to observe more easily if he could manage without cardiac pacing: this later proved to be the case.

In the case of the woman, recurrent perforations of the cable through the skin of the jugular fossa occurred, accompanied by a slight infection which did not heal until the mediastinal atrial electrode was removed.

In 3 patients, aged 70 to 80 , atrial triggered cardiac pacing was temporarily interrupted and changed to ventricular synchronised pacing. In 2 cases this was done because of varying $P$ waves, which were partly inefficient. All 3 patients, however, felt pronounced discomfort with breathlessness and decreased physical fitness, and the cardiac pacing was again changed to atrial triggered cardiac pacing. In case 3 a pulse generator with higher sensitivity to the $\mathbf{P}$ waves functioned well.

\section{Discussion}

With regard to the capability of recording an adequate $\mathrm{P}$ wave, the mediastinal atrial electrode has shown good results initially, with an effective $P$ wave in 80 out of 82 cases. A preoperative screening of the mediastinal $P$ wave should preferably be done by an oesophageal electrode to exclude patients with $P$ waves unsuitable for a mediastinal atrial electrode.

The stability of the sinus rhythm should be checked by repeated electrocardiograms including one during exercise. An exercise test with increasing rate of the external pulse generator should also be done to eliminate patients who get anginal pains with increasing heart rate. Some of the early patients in this case material are not representative of patients selected for atrial triggered cardiac pacing more recently. In the early group it was started because of interference between fixed rate pacing and transmitted beats and because atrial triggered cardiac pacing was the first available method of synchronised pacing in this hospital. This explains why it was necessary to replace it with ventricular synchronised pacing in some of the early patients in this study.

The surgical procedure gave very little stress to the patients, and was free from complications with the exception of an easily corrected perforation of the electrode into the pericardium, which was seen in 2 patients. This might have been caused by excessive force on the suction tube.

The atrial fibrillation observed in one patient after implantation of mediastinal atrial electrode continued even after extraction of the electrode. It is possible, however, that the mechanical irritation may have provoked atrial fibrillation in a predisposed patient. The atrial fibrillation and flutter observed in 2 patients later on during atrial triggered cardiac pacing seems to be coincidental and an unpredictable cause of terminating it.

The regular decrease of the $P$ wave after operation is most probably caused by tissue reaction against the electrode. During this period ineffectiveness of the $P$ wave without visible displacement on $x$-ray film occurred only twice. The cause may have been extreme tissue reaction or minor displacement of the electrode. Visible displacement of the mediastinal atrial electrode with an ineffective $P$ wave occurred in 10 patients up to 4 years after starting atrial triggered cardiac pacing. In some patients the cause was obviously an extreme traction of the mediastinal atrial electrode, as described above. After one week the $P$ wave was usually stable during the years of observation. Several mediastinal atrial electrodes are still functioning after 10 years.

The mediastinal atrial electrode has previously been described as a promising method for atrial triggered cardiac pacing (Carlens et al., 1965; Lagergren et al., 1966a, b; Larsson et al., 1969; Larsson, 1970; Kleinert and Nahrstedt, 1974). Larsson et al. (1969) presented results similar to this study, with no surgical complication and a displacement frequency of about 10 per cent.

The problem of displacement occurs with other types of electrodes, and our experience shows the importance of securing the electrode and of avoiding traction of it. For practical reasons and to reduce the risk of infection, Larsson et al. (1969) have suggested that it is preferable to do one stage implantation of the mediastinal atrial electrode and the atrial triggered pulse generator, even if early displacement of the electrode can still happen.

Apart from the mediastinal atrial electrode (Carlens et al., 1965; Lagergren et al., 1966a, b; Larsson et al., 1969; Larsson, 1970; Kleinert and Nahrstedt, 1974) there are two main approaches for introducing the electrode: implantation via thoracotomy (Center et al., 1963, 1964; Nathan et al., 1964; Center and Nathan, 1966; Silverman et al., 1968; Nusbaum and Levit, 1970; Cleveland et al., 1972; Mills and Ochsner, 1973; Perryman and Sealy, 1973) and transvenous techniques (Rodewald et al., 1964; Center and Castillo, 1967; Center 
et al., 1967; Hunt and Sloman, 1968; Kastor et al., 1969; Moss et al., 1969; Kramer and Moss, 1970a, b; Kitamura et al., 1971; Vogel et al., 1971; Rosenkranz and Schaldach, 1971; Bleifeld et al., 1971; Smyth et al., 1971a, b; Porstmann et al., 1972; Zucker et al., 1973; Cappelen and Hall, 1974; Moss et al., 1974; Obel and Scott Millar, 1975; Rubenfire, 1975). Reviews of different methods have been given by Dodinot et al. (1969), Sowton (1969), Benchimol and Goldstein (1969), Nathan et al. (1971), DeSanctis (1971), and Furman (1973).

The first method described and still most widely used is implantation via thoracotomy. With this method the electrode can be fixed directly on the atrium to ensure stability of the electrode. However, the method involves a relatively high risk, as stressed by Dodinot et al. (1969). In order to avoid such a major operation other surgical routes to the epicardium have been developed. The retrosternal approach through a subxiphoid incision (Behrends et al., 1965; Bruck and Spang, 1966) seems to offer no significant advantages over thoracotomy.

The problem of the transvenous atrial electrode is the high frequency of electrode displacements (DeSanctis, 1971; Zucker et al., 1973). However, Bleifeld et al. (1971), Rosenkranz and Schaldach (1971), and Vogel et al. (1971) have reported series of operations almost free from complications. Their methods involved using an electrode held tightly to the atrial wall by barbs or hooks on the electrode tip.

Among other transvenous methods, the J-shaped wires described and used by Kastor et al. (1969) and Smyth et al. (1971a, b) may be handled and inserted easily but the displacement frequency is high. Zucker et al. (1973) described a moderately successful modification of this method. Placing the transvenous electrode in the coronary vein (Hunt and Sloman, 1968; Moss et al., 1969; Kramer and Moss, 1970a, b; Kitamura et al., 1971; Moss et al., 1974; Obel and Scott Millar, 1975; Rubenfire, 1975) has been used for long-term pacing. The potential risk of thrombosis and perforation must be considered but, as far as we know, only one case with perforation has been reported (Kitamura et al., 1971): this occurred with a temporary electrode used in addition for infusion. The experience of this technique is still limited but promising results with low thresholds at generator replacements are reported by Moss et al. (1974).

In conclusion, the mediastinal atrial electrode has shown results that are comparable with the best results discussed above and the method has been s lown to be suitable for long-term treatment.

The mediastinal atrial electrode has often been described as involving too high a risk and as being too difficult for general use, but our experience has shown that the method is technically simple and places little stress on the patient. It is, therefore, recommended as a good alternative for $\mathbf{P}$ wave detection.

\section{References}

Battye, C. K., and Weale, F. E. (1960). The use of the P-wave for control of a pacemaker in heart block. Thorax, 15, 177-180.

Behrends, W., Bruck, A., Fürnrohr, H., and Mahringer, W. (1965). Implantation vorhofgesteuerter Schrittmacher ohne Thorakotomie an der Herzbasis. Zeitschrift für Kreislaufforschung, 54, 934-936.

Benchimol, A., and Goldstein, M. (1969). A review of atrial pacing: clinical and laboratory applications. Annals of the New York Academy of Sciences, 167, 604-613.

Bleifeld, W., Irnich, W., and Effert, S. (1971). A new transvenous electrode with myocardial fixation for permanent pacing. Digest Ninth International Conference of Medical and Biological Engineering, Melbourne, Australia, p. 76.

Bruck, A., and Spang, K. (1966). Der vorhofgesteuerte Schrittmacher. Zeitschrift für Kreislaufforschung, 55, 282-297.

Cappelen, Chr., and Hall, K. V. (1974). Pervenous atrial electrode. Scandinavian Fournal of Thoracic and Cardiovascular Surgery, 8, 115-118.

Carlens, E. (1959). Mediastinoscopy: a method for inspection and tissue biopsy in the superior mediastinum. Diseases of the Chest, 36, 343-352.

Carlens, E., Johansson, L., Karlöf, I., and Lagergren, $\mathbf{H}$. (1965). New method for atrial-triggered pacemaker treatment without thoracotomy. Fournal of Thoracic and Cardiovascular Surgery, 50, 229-232.

Center, S., and Castillo, C. (1967). Pervenous synchronous pacing. Fournal of Thoracic and Cardiovascular Surgery, 53, 508-510.

Center, S., Castillo, C., and Keller, W. (1967). Permanent pervenous synchronous pacing of the heart. Annals of Thoracic Surgery, 4, 218-231.

Center, S., and Nathan, D. (1966). The synchronous pacer. Three years of clinical experience with 45 cases. Annals of Surgery, 164, 862-866.

Center, S., Nathan, D., Wu, C.-Y., and Duque, D. (1964). Two years of clinical experience with the synchronous pacer. Fournal of Thoracic and Cardiovascular Surgery, 48, 513-524.

Center, S., Nathan, D., Wu, C.-Y., Samet, P., and Keller, W. (1963). The implantable synchronous pacer in the treatment of complete heart block. Fournal of Thoracic and Cardiovascular Surgery, 46, 744-753.

Cleveland, R., Nelson, R., Zeilenga, D., and Lippmann, $M$. (1972). Atrial pacing following open-heart surgery. Archives of Surgery, 105, 26-29.

DeSanctis, R. (1971). Diagnostic and therapeutic uses of atrial pacing. Circulation, 43, 748-761.

Dodinot, B. P., Petitier, H. A., Gilgenkrantz, J. M., and Faivre, G. R. (1969). Clinical experience with atrialsynchronous pacing. Annals of the New York Academy of Sciences, 167, 1038-1054.

Elmqvist, R., and Senning, Å. (1960). Implantable pacemaker for the heart. In Medical Electronics, Proceedings of the 2nd International Conference, p. 253. Ed. by C. N. Smyth. Charles C. Thomas, Springfield, Illinois.

Folkman, M. J., and Watkins, E. (1957). An artificial conduction system for the management of experimental complete heart block. Surgical Forum, 8, 331-334. 
Furman, S. (1973). Therapeutic uses of atrial pacing. American Heart fournal, 86, 835-840.

Furman, S., and Schwedel, J. B. (1959). An intracardiac pacemaker for Stokes-Adams seizures. New England fournal of Medicine, 261, 943-948.

Glenn, W. W. L., Mauro, A., Longo, E., Lavietes, P. H., and MacKay, F. J. (1959). Remote stimulation of the heart by radio-frequency transmission: clinical application to a patient with Stokes-Adams syndrome. New England fournal of Medicine, 261, 948-951.

Hunt, D., and Sloman, G. (1968). Long-term electrode catheter pacing from coronary sinus. British Medical Fournal, 4, 495-496.

Kastor, J., DeSanctis, R., Leinbach, R., Harthorne, J. W., and Wolfson, I. N. (1969). Long-term pervenous atrial pacing. Circulation, 40, 535-544.

Kitamura, K., Jorgensen, C. R., and From, A. H. L. (1971). Transvenous atrial and ventricular pacing from the coronary sinus complicated by perforation and cardiac tamponade. Chest, 60, 95-98.

Kleinert, M., and Nahrstedt, J. (1974). Zur transmediastinalen Verlegung von Detektorelektroden bei vorhofgesteuerten elektrischen Stimulationssystemen. Zeitschrift für Kardiologie, 63, 862-868.

Kramer, D. H., and Moss, A. (1970a). Permanent pervenous atrial pacing for treatment of symptomatic sinus bradycardia (abstract). American fournal of Cardiology, 25, 111.

Kramer, D. H., and Moss, A. (1970b). Permanent pervenous atrial pacing from the coronary vein. Circulation, 42, 427-436.

Lagergren, H., Johansson, L., Karlöf, I., and Thornander, H. (1966a). Atrial-triggered pacemaking without thoracotomy: apparatus and results in twenty cases. Acta Chirurgica Scandinavica, 132, 678-695.

Lagergren, H., Johansson, L., Karlöf, I., and Thornander, H. (1966b). Ein neuer vorhofsgesteuerter Schrittmacher. Thoraxchirurgie, 14, 594-597.

Larsson, S. (1970). Mediastinoscopy in pacemaker treatment. Mediastinoscopy. In Proceedings of an International Symposium, Odense University.

Larsson, S., Alestig, K., Bojs, G., and Bergh, N. P. (1969). Treatment by atrial-triggered pacemaker. Scandinavian Fournal of Thoracic and Cardiovascular Surgery, 3, 186-194.

Mills, N., and Ochsner, J. (1973). Experience with atrial pacemaker wires implanted during cardiac operations. fournal of Thoracic and Cardiovascular Surgery, 66, 878-885.

Moss, A., Rivers, R., and Cooper, M. (1969). Long-term pervenous atrial pacing from the proximal portion of the coronary vein. Fournal of the American Medical Association, 209, 543-545.

Moss, A., Rivers, R., and Kramer, D. (1974). Permanent pervenous atrial pacing from the coronary vein. Long-term follow-up. Circulation, 49, 222-225.

Nathan, D. A., Center, S., Samet, P., Wu, C.-Y., and Keller, J. W. (1964). The application of an unplantable synchronous pacer for the correction of Stokes-Adams attacks. Annals of the New York Academy of Sciences, 111, 10931104.

Nathan, D. A., Center, S., Wu, C.-Y., and Keller, W. (1963). An implantable synchronous pacemaker for the long term correction of complete heart block. American fournal of Cardiology, 11, 362-367.
Nathan, D., Lister, J., Castillo, R., Keller, W., and Gossellin, A. (1971). Current status of atrial pacing. Annales de Cardiologie et d'Angéiologie, 20, 451-456.

Nusbaum, M., and Levit, S. (1970). Technique for permanent implantation of atrial pacemaker. Surgery, 68, 916-918.

Obel, I. W. P., and Scott Millar, R. N. (1975). Long-term coronary sinus pacing. Chest, 67, 741 .

Perryman, R., and Sealy, W. (1973). Permanent atrial pacing. Annals of Thoracic Surgery, 15, 16-24.

Porstmann, W., Witte, J., Dressler, L., Schaldach, M., Vogel, I., and Warnke, H. (1972). P-wave synchronous pacing using anchored atrial electrode implanted without thoracotomy. American fournal of Cardiology, 30, 74-76.

Rodewald, G., Giebel, O., Harms, H., and Scheppokat, K. D. (1964). Intravenös-intrakardiale applikation von vorhofgesteurerten elektrischen Schrittmachern. Zeitschrift für Kreislaufforschung, 53, 860-864.

Rosenkranz, K. A., and Schaldach, M. (1971). Transvenösendokardiale vorhofsteuerung von Schrittmachern. Deutsche medizinische Wochenschrift, 96, 680-686.

Rubenfire, M. (1975). Long-term coronary sinus pacing. Chest, 67, 741.

Senning, $\AA$. (1959). Discussion of paper by Stephenson, S. E., Jr., Edwards, W. H., Jolly, P. C., and Scott, H. W., Jr. Physiologic P-wave cardiac stimulator q.v. Fournal of Thoracic and Cardiovascular Surgery, 38, 639.

Silverman, L., Mankin, H., and McGoon, D. (1968). Surgical treatment of an inadequate sinus mechanism by implantation of a right atrial pacemaker electrode. Fournal of Thoracic and Cardiovascular Surgery, 55, 264-270.

Smyth, N., Keshishian, J., Bacos, J., Massumi, R., Fletcher, R., and Boivin, M. (1971a). Permanent pervenous atrial pacing. Fournal of Electrocardiology, 4, 299-306.

Smyth, N., Keshishian, J., Basu, A., Bacos, J., Massumi, R., Fletcher, R., and Baker, N. (1971b). Permanent transvenous atrial pacing: an experimental and clinical study. Annals of Thoracic Surgery, 11, 360-370.

Sowton, E. (1969). Panel discussion II. Annals of the New York Academy of Sciences, 167, 1067-1075.

Stephenson, S. E., Jr., Edwards, W. H., Jolly, P. C., and Scott, H. W., Jr. (1959). Physiologic P-wave cardiac stimulator. Fournal of Thoracic and Cardiovascular Surgery, 38, 604-609.

Vogel, I., Dressler, L., Witte, J., Warnke, H., Porstmann, P., and Schaldach, M. (1971). Atrial synchronized pacing using a new transvenous technique. Annales de Cardiologie et d'Angéiologie, 20, 381-389.

Weirich, W. L., Gott, V. L., and Lillehei, C. W. (1957). The treatment of complete heart block by the combined use of a myocardial electrode and an artificial pacemaker. Surgical Forum, 8, 360-363.

Zucker, R., Parsonnet, V., and Gilberg, L. (1973). A method of permanent transvenous implantation of an atrial electrode. American Heart fournal, 85, 195-198.

Requests for reprints to Dr. K. Pehrsson, Department of Medicine, Karolinska Institut, S-104 01 Stockholm 60, Sweden. 